\title{
Effects of manganese on growth and development of peanut (Arachis hypogaea L.) seedlings
}

\author{
Ying Liu ${ }^{1}$, Jingye Chen ${ }^{1}$, Xiaohao $\mathrm{Li}^{1}$ and Yingbin $\mathrm{Xue}^{2^{*}}$ \\ ${ }^{1}$ College of Coastal Agricultural Sciences, Guangdong Ocean University, Zhanjiang 524088, P.R. China \\ ${ }^{2}$ College of Chemistry and Environment, Guangdong Ocean University, Zhanjiang 524088, P.R. China \\ *Author for correspondence: Yingbin Xue, yingbinxue@yeah.net
}

\begin{abstract}
The effects of different menganses (Mn) concentrations on the growth and development of peanut seedlings were analysed in the present study. The results showed that the main root length, lateral root number, plant height, dry weight of aboveground and underground parts of peanut seedlings were all influenced by the concentrations of Mn obviously. Moreover, the growth of peanut could be significantly promoted at low concentration of $\mathrm{Mn}(150 \mu \mathrm{mol} / \mathrm{L})$, while inhibited by high concentration of $\mathrm{Mn}(900$ $\mu \mathrm{mol} / \mathrm{L})$. Therefore, these conclusions could help us to understand the most suitable concentration range of $\mathrm{Mn}$ for the growth of peanut, and could also analyze the specific performance of the harm of Mn toxicity on peanut, so as to lay a theoretical foundation for improving the yield of peanut and expanding the cultivation area.
\end{abstract}

\section{Introduction}

Arachis hypogaea is an annual herb of the genus of Arachis in leguminous family [1]. The provinces of Shandong, Guangdong, Guangxi, Hebei, Henan, Liaoning, Anhui and Sichuan are the main producing areas of peanut in China [2]. Peanut is an important oil and cash crop [3], which can be used to extract edible oil, as lubricant in textile industry, and as quenching agent in machine manufacturing industry and so on [4]. Peanut is rich in oil and protein. The oil contains 19\%-43\% linoleic acid, which is the essential fatty acid for human body, and its protein contains a large number of essential amino acids for human body; and the composition proportion of oil and protein is appropriate, and the effective utilization rate is also high [4]. In addition, it also contains calcium, iron, phosphorus and a variety of vitamins, which are extremely rich in nutrients and play a very important role in human growth and disease resistance maintenance [4].

Plants growing in acid soil will be affected by many obstacles in the growth and development process, among which $\mathrm{Mn}$ toxicity is one of the main toxic factors [5]. Mn toxicity is the limiting factor of plant growth in acid soil second only to aluminum toxicity [6]. Moreover, the acid soil in China accounts for $21 \%$ of the cultivated land area, and peanut is planted in a large area in China. Meanwhile, affected by sewage irrigation, industrial waste residue, industrial waste piling, urban garbage and atmospheric deposition, etc., the high concentration of $\mathrm{Mn}$ is easy to cause Mn toxicity [7]. Mn toxicity can significantly reduce the yield of peanut, and excess $\mathrm{Mn}$ are enriched in peanut and can accumulate in human body through the food chain, causing harm to human body $[8,9]$. Therefore, studying the effects of $\mathrm{Mn}$ on peanut could help us to understand the most suitable concentration range of $\mathrm{Mn}$ for the growth of peanut, and could also analyze the specific performance of the harm of Mn toxicity on peanut, so as to lay a theoretical foundation for improving the yield of peanut and expanding the cultivation area.

Compared to the complex soil environment, the ion concentration, $\mathrm{pH}$ and temperature conditions are easier to be controled under hydroponic environment, in which the interference of many unknown factors in the soil can be eliminated. So that, hydroponic experiment was used to study the effects of Mn on seedling growth of peanut in the present study. The results might provide references for studying the mechanism of transport and absorption of other ions in plants.

\section{Materials and Methods}

\subsection{Experimental materials}

The peanut seeds, named Dabaisha 171 were purchased from Yantai Qishan Seed Co., Ltd in China.

\subsection{Experiment reagents}

The hydroponic nutrient solution is an improved Hoagland nutrient solution [10]. $\mathrm{NH}_{4} \mathrm{NO}_{3}, \mathrm{MgCl}_{2} \cdot 6 \mathrm{H}_{2} \mathrm{O}$, $\mathrm{C}_{10} \mathrm{H}_{12} \mathrm{FeN}_{2} \mathrm{NaO}_{8} \cdot 3 \mathrm{H}_{2} \mathrm{O}, \quad \mathrm{MgSO}_{4} \cdot 7 \mathrm{H}_{2} \mathrm{O}, \quad \mathrm{K}_{2} \mathrm{SO}_{4}$, $\left(\mathrm{NH}_{4}\right)_{2} \mathrm{SO}_{4}, \quad \mathrm{ZnSO}_{4} \cdot 7 \mathrm{H}_{2} \mathrm{O}, \quad\left(\mathrm{NH}_{4}\right)_{6} \mathrm{Mo}_{7} \mathrm{O}_{24} \cdot 4 \mathrm{H}_{2} \mathrm{O}$, $\mathrm{KH}_{2} \mathrm{PO}_{4}, \quad \mathrm{Na}_{2} \mathrm{~B}_{4} \mathrm{O}_{7} \cdot 10 \mathrm{H}_{2} \mathrm{O}, \quad \mathrm{Ca}\left(\mathrm{NO}_{3}\right)_{2} \cdot 4 \mathrm{H}_{2} \mathrm{O}$, 
$\mathrm{CuSO}_{4} \cdot 5 \mathrm{H}_{2} \mathrm{O}, \mathrm{MnSO}_{4} \cdot \mathrm{H}_{2} \mathrm{O}$, and $\mathrm{KNO}_{3}$ were purchased from Beijing Solarbio Science \& Technology Co., Ltd in China.

\subsection{Experimental apparatus}

The main instruments required for the experiment were: electric heat distilled water device (YN-ZD-Z), magnetic stirrers (MS-H280-Pro), analytical balance (DTTFA200), micropipetteor (Eppendorf), pH meter (PHS$3 \mathrm{E})$, refrigerators (BCD-201E/A), air conditioning (KFR-35G/A9(D)-D2), LED light (ODT514), electric heating blast drying oven (PCHB-C6000) and water purifier (MRC1796A-400G), etc.

\subsection{Experimental methods}

\subsubsection{Seed germination}

The peanut seeds with good color were selected as the material, which were neatly inoculated into the sterilized quartz sand with spaced 2-3 cm apart. After sowing, the sand layer with a thickness of $2 \mathrm{~cm}$ was overlaid on the seeds in cultivating box. And then the seeds were placed in a greenhouse with light intensity of 1500-2000 Lx at $25^{\circ} \mathrm{C}$, and the light time was $12 \mathrm{~h} /$ day.

\subsubsection{Preparation of nutrient solutions}

The hydroponic nutrient solutions containing $0,150,300$, 600 and $900 \mu \mathrm{mol} / \mathrm{L} \mathrm{MnSO}_{4}$ were prepared according to the reported methods [11], respectively.

\subsubsection{Peanut seedlings were treated with hydroponics}

The seedlings of peanut cultured in quartz sand for 5 days were transplanted into plastic boxes (length $\times$ width $\times$ height $=67 \times 42 \times 15 \mathrm{~cm}) \quad$ with hydroponic nutrient solution contained various concentrations of $\mathrm{MnSO}_{4}(0,150,300,600$ and 900 $\mu \mathrm{mol} / \mathrm{L}$ ) and treated for 15 days, respectively. The nutrient solution should be replaced every 5 days and the $\mathrm{pH}$ should be adjusted to $\mathrm{pH}=4.9-5.0$ every 3 days.

\subsubsection{Data recording}

The data of lateral root number, main root length, plant height, dry weight of aboveground and underground parts were measured respectively in 5 replicates of each treatment on the 0,5 and 10 days after the peanut seedlings transferred into the hydroponic nutrient solution contained various concentrations of $\mathrm{MnSO}_{4}(0$, 150, 300, 600 and $900 \mu \mathrm{mol} / \mathrm{L})$.

\subsubsection{Data processing}

Excel software was used to input and calculate the data, and SPSS 20.0 statistical analysis software was used for variance analysis and Duncan's multiple comparison
$(P \leq 0.05)$. The significant difference was marked with different lowercase letters.

\section{Results}

\subsection{Effects of different Mn concentration on plant height of peanut seedlings}

According to Table 1 and Figure 1(A-D), the results suggested that the plant height of peanut seedlings firstly increased and then decreased with the increase of $\mathrm{Mn}$ concentration. The value of plant height was the highest when $\mathrm{Mn}$ concentration was $150 \mu \mathrm{mol} / \mathrm{L}$, followed by $300 \mu \mathrm{mol} / \mathrm{L}$ on the 10 th day, but there was no significant difference between the two treatments. However, when $\mathrm{Mn}$ was at the concentration of $900 \mu \mathrm{mol} / \mathrm{L}$, the plant height of peanut was the lowest, indicating that high concentration of Mn might inhibit the growth of peanut seedlings. In conclusion, 150 or $300 \mu \mathrm{mol} / \mathrm{L}$ of $\mathrm{Mn}$ might be the suitable concentration for growth of peanut seedlings.

Table 1. Effects of different Mn concentrations on plant height of peanut seedlings

\begin{tabular}{|c|c|c|c|}
\hline \multirow{2}{*}{$\begin{array}{c}\text { Concentrations } \\
\text { of } \begin{array}{c}\mid 3 \\
(\mu \mathrm{mol} / \mathrm{L})\end{array}\end{array}$} & 0 day & 5 th day & 10 th day \\
\cline { 2 - 4 } & $6.02 \pm 0.18 \mathrm{a}$ & $8.62 \pm 0.21 \mathrm{a}$ & $12.30 \pm 0.06 \mathrm{~b}$ \\
\hline 0 & $6.14 \pm 0.23 \mathrm{a}$ & $9.41 \pm 0.74 \mathrm{a}$ & $13.77 \pm 0.18 \mathrm{a}$ \\
\hline 150 & $6.09 \pm 0.15 \mathrm{a}$ & $9.15 \pm 0.49 \mathrm{a}$ & $13.60 \pm 0.12 \mathrm{a}$ \\
\hline 300 & $6.17 \pm 0.12 \mathrm{a}$ & $8.42 \pm 0.15 \mathrm{a}$ & $12.20 \pm 0.09 \mathrm{~b}$ \\
\hline 600 & $6.23 \pm 0.22 \mathrm{a}$ & $8.83 \pm 0.18 \mathrm{a}$ & $11.47 \pm 0.15 \mathrm{c}$ \\
\hline 900 & &
\end{tabular}

Note: Different letters in the same column indicate significant difference at $P \leqslant 0.05$ level.

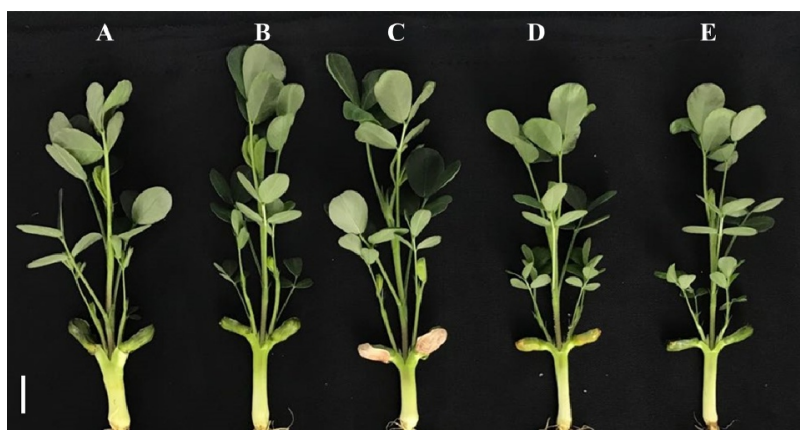

Figure.1 Effects of different Mn concentrations on plant height of peanut seedlings on the 10th day.

A: $0 \mu \mathrm{mol} / \mathrm{L}$; B: $150 \mu \mathrm{mol} / \mathrm{L}$; C: $300 \mu \mathrm{mol} / \mathrm{L}$; D: $600 \mu \mathrm{mol} / \mathrm{L}$; E: $900 \mu \mathrm{mol} / \mathrm{L}$. (Bars=2 cm) 


\subsection{Influences of different Mn concentrations on main root length of peanut seedlings}

In order to investigate the effects of different concentrations of $\mathrm{Mn}$ on the root length of peanut seedlings, the root length was measured and statistically analysed at 0,5 and 10 days after transplantation, and the results were shown in Table 2. After 5 days of culture, the maximum of root length was achieved at the concentrations of 150 and $300 \mu \mathrm{mol} / \mathrm{L}$. The longest root was obtained on the 10th day, while the root length was significantly lower than that of the other treatments at the $900 \mu \mathrm{mol} / \mathrm{L} \mathrm{Mn}$, indicating that high concentration of Mn inhibited root growth of peanut seedlings.

Table 2. Results of different Mn concentrations on main root length of peanut seedlings

\begin{tabular}{|c|c|c|c|}
\hline \multirow{2}{*}{$\begin{array}{c}\text { Concentrations } \\
\text { of } \mathrm{MnSO}_{4} \\
(\mu \mathrm{mol} / \mathrm{L})\end{array}$} & 0 day & 5 th day & 10 th day \\
\cline { 2 - 4 } & $11.82 \pm 0.62 \mathrm{a}$ & $13.40 \pm 0.65 \mathrm{ab}$ & $19.21 \pm 0.12 \mathrm{c}$ \\
\hline 0 & $11.78 \pm 0.28 \mathrm{a}$ & $14.80 \pm 0.39 \mathrm{a}$ & $23.27 \pm 0.24 \mathrm{a}$ \\
\hline 150 & $11.86 \pm 0.36 \mathrm{a}$ & $14.53 \pm 0.17 \mathrm{a}$ & $21.10 \pm 0.29 \mathrm{~b}$ \\
\hline 300 & $11.75 \pm 0.41 \mathrm{a}$ & $13.00 \pm 0.29 \mathrm{~b}$ & $16.07 \pm 0.34 \mathrm{~d}$ \\
\hline 600 & $11.91 \pm 0.59 \mathrm{a}$ & $12.70 \pm 0.42 \mathrm{~b}$ & $13.03 \pm 0.42 \mathrm{e}$ \\
\hline 900 &
\end{tabular}

Note: Different letters in the same column indicate significant difference at $P \leqslant 0.05$ level.

\subsection{Results of different Mn concentrations on lateral root number of peanut seedlings}

As seen in Table 3, the formation of lateral roots was affected by the concentration of Mn. The largest number of lateral roots of peanut seedlings was gained when $\mathrm{Mn}$ was at the concentrations of $0-300 \mu \mathrm{mol} / \mathrm{L}$ on the fifth day. Furthermore, the highest number of lateral roots acquired on the 10th day, when $\mathrm{Mn}$ was 0 and 150 $\mu \mathrm{mol} / \mathrm{L}$. However, when Mn was above $300 \mu \mathrm{mol} / \mathrm{L}$, the number of lateral roots gradually decreased, and the lowest number of lateral roots was received at the concentration of $900 \mu \mathrm{mol} / \mathrm{L}$. The results showed that the growth of lateral roots might be inhibited at high concentration of $\mathrm{Mn}$.

Table 3. Effects of different Mn concentrations on lateral root number of peanut seedlings

\begin{tabular}{|c|c|c|c|}
\hline $\begin{array}{c}\text { Concentrations } \\
\text { of } \mathrm{MnSO}_{4} \\
(\mu \mathrm{mol} / \mathrm{L})\end{array}$ & \multicolumn{3}{|c|}{ Number of lateral roots } \\
\cline { 2 - 4 } & 0 day & 5 th day & 10 th day \\
\hline 0 & $40.33 \pm 2.03 \mathrm{a}$ & $74.00 \pm 2.07 \mathrm{a}$ & $92.00 \pm 1.00 \mathrm{a}$ \\
\hline 150 & $40.54 \pm 1.05 \mathrm{a}$ & $72.21 \pm 2.65 \mathrm{a}$ & $91.67 \pm 1.39 \mathrm{a}$ \\
\hline 300 & $40.68 \pm 2.12 \mathrm{a}$ & $71.33 \pm 1.89 \mathrm{ab}$ & $80.33 \pm 1.95 \mathrm{~b}$ \\
\hline 600 & $40.74 \pm 1.58 \mathrm{a}$ & $69.67 \pm 1.45 \mathrm{~b}$ & $77.33 \pm 2.11 \mathrm{c}$ \\
\hline 900 & $41.36 \pm 1.24 \mathrm{a}$ & $66.67 \pm 1.63 \mathrm{~b}$ & $54.00 \pm 2.65 \mathrm{~d}$ \\
\hline
\end{tabular}

Note: Different letters in the same column indicate significant difference at $P \leqslant 0.05$ level.

\subsection{Effects of various Mn concentrations on dry weight of peanut seedlings}

In order to investigate the effects of Mn on dry weight, the peanut seedlings were dried on the 10th day after transplantation, and the dry weight of the aboveground and underground parts were measured respectively. From the data in Table 4, the dry weights of aboveground and underground parts from 150 to 300 $\mu \mathrm{mol} / \mathrm{L} \mathrm{Mn}$ were higher than that from 600 to 900 $\mu \mathrm{mol} / \mathrm{L} \mathrm{Mn}$. While the dry weight would decrease when the concentration of $\mathrm{Mn}$ over $300 \mu \mathrm{mol} / \mathrm{L} \mathrm{Mn}$, and the minimum of dry weight was gained at the concentration of $900 \mu \mathrm{mol} / \mathrm{L} \mathrm{Mn}$.

Table 4. Effects of different Mn concentrations on dry weight of peanut seedlings

\begin{tabular}{|c|c|c|}
\hline \multirow{2}{*}{$\begin{array}{c}\text { Concentrations of } \\
\mathrm{MnSO}_{4}(\mu \mathrm{mol} / \mathrm{L})\end{array}$} & \multicolumn{2}{|c|}{ Dry weight $(\mathrm{g})$} \\
\cline { 2 - 3 } & Underground part & Overground part \\
\hline 0 & $0.14 \pm 0.01 \mathrm{ab}$ & $0.65 \pm 0.03 \mathrm{ab}$ \\
\hline 150 & $0.17 \pm 0.02 \mathrm{a}$ & $0.71 \pm 0.05 \mathrm{a}$ \\
\hline 300 & $0.15 \pm 0.01 \mathrm{a}$ & $0.67 \pm 0.04 \mathrm{a}$ \\
\hline 600 & $0.13 \pm 0.01 \mathrm{~b}$ & $0.59 \pm 0.03 \mathrm{~b}$ \\
\hline 900 & $0.11 \pm 0.01 \mathrm{~b}$ & $0.45 \pm 0.04 \mathrm{c}$ \\
\hline
\end{tabular}

Note: Different letters in the same column indicate significant difference at $P \leqslant 0.05$ level.

\section{Discussion}

Our results suggested that the growth and development of peanut seedlings would increase firstly and then decrease with the increase of Mn concentration, indicating that low concentration of $\mathrm{Mn}$ could significantly promote the growth of peanut, while high concentration of Mn could inhibit the growth of peanut seedlings. Some studies have shown that a large amount of $\mathrm{Mn}$ can be transported into the growing plant tissues, which increases the activity of auxin oxidase and destroys the auxin, resulting in the lack of auxin in the plant tissues, thus affecting the increase of plant height [5]. In addition, high concentration of Mn could inhibit the accumulation of dry matter in the upper and underground parts of the peanut seedlings. This may be because the growth of root is inhibited by high concentration of $\mathrm{Mn}$ severely, and then the growth of aboveground part will be impeded, leading to the reduction of biomass [12]. And there are other studies that show that when plants absorb excessive Mn, leading to reduce plant photosynthetic efficiency and chlorophyll content, young leaf etiolation, increase of superoxide dismutase (SOD) activity $[13,14]$. High menganes also seriously affects plant growthm development and yield [15]. Therefore, Mn toxicity stress can cause great harm 
to plants and has become an important factor limiting plant growth and development $[16,17]$.

\section{Conclusion}

In the present study, the effects of different $\mathrm{Mn}$ concentrations on the growth and development of peanut seedlings were investigated. These results suggested that the main root length, lateral root number, plant height, dry weight of aboveground and underground parts of peanut seedlings were all affected by the concentrations of Mn obviously. Furthermore, the growth of peanut could be significantly promoted at low concentration of Mn $(150 \mu \mathrm{mol} / \mathrm{L})$, while high concentration of Mn (900 $\mu \mathrm{mol} / \mathrm{L}$ ) could inhibit the growth of peanut seedlings.

\section{Acknowledgement}

This research was funded by the Natural Science Foundation of Guangdong Province (2018A030310057 and 2020A1515011570), Nanhai Youth Scholar Project of Guangdong Ocean University (002029001012), Program for Scientific Research Start-up Funds of Guangdong Ocean University (R17023 and R19031), Foundation of Education Department of Guangdong Province (2019KTSCX059), the Project of Science and Technology of Zhanjiang City (2020B01019), the National Natural Science Foundation of China (32002131).

\section{References}

1. C.L. Yuan, C.X. Yan, X.B. Zhao, et al. Research progress of peanut mutants. J. Nucl Agr. Sci. 34, 7884 (2020)

2. Y. Wang. Comparative advantage of main peanut producing areas in China. Nanjing Agr. Univ. 2013.

3. H.D. Upadhyaya, S.N. Nigam, S. Singh. Evaluation of groundnut core collections to identify sources of tolerance to low temperature at germination. Inter. Crop. Res. Inst. Semi. Arid. Tropis. 14, 165-167 (2001)

4. G.X. Zhao, X. Chen, H.F. Liu, et al. Study on functional components, nutritional value and development and utilization of peanut. Anhui Agr. Sci. Bull. 17, 39-42 (2011)

5. X.K Zhang, F.S. Zhang, D.R. Mao. Advances in studies on manganese poisoning in plants. Progr. Pedol. 22, 13-21 (1994)

6. C.D. Foy. Physiological effects of hydrogen, aluminum, and manganese toxicities in acid soil. Am. Soc. Agron. 12, 57-97 (1984)

7. Y. Xiong, Q.K. Li. Soil of China. Sci. Press. 1987.

8. R. Lucchini, D. Placidi, G. Cagna, et al. Manganese and developmental neurotoxicity. Adv. Neurobiol. 18, 13-34 (2017)

9. P.D. Liu, R. Huang, X. Hu, et al. Physiological responses and proteomic changes reveal insights into Stylosanthes response to manganese toxicity. BMC Plant Biol. 19, 1-21 (2019)

10. R. Hoagland. The water culture methods for growing plants without soil. Calif. Agr. Exp. Stat. Circ. 347, 1-32 (1950)

11. Y. Liu, Y.B. Xue, B.X. Xie, et al. Complex gene regulation between young and old soybean leaves in responses to manganese toxicity. Plant Physiol. Biochem. 155, 231-242 (2020)

12. L.F. Xia, M. Cai, F. Li. Adaptation difference and manganese tolerance pathway of three legumes under manganese toxic stress. Dev. West China. 2, 60-67 (2017)

13. Z.J. Chen, L.L. Sun, P.D. Liu, et al. Malate synthesis and secretion mediated by a manganeseenhanced malate dehydrogenase confers superior manganese tolerance in Stylosanthes guianensis. Plant Physiol. 167, 176-88 (2015)

14. A. Shrestha, A.K. Dziwornu, Y. Ueda, et al. Genome-wide association study to identify candidate loci and genes for Mn toxicity tolerance in rice. PLoS One, 13, e0192116 (2018)

15. F.M. Yu, Y. Li, F.R. Li, et al. The effects of EDTA on plant growth and manganese $(\mathrm{Mn})$ accumulation in polygonum pubescens blume cultured in unexplored soil, mining soil and tailing soil from the pingle Mn mine, China. Ecotox. Environ. Safe. 173, 235-242 (2019)

16. J.F. Shao, N. Yamaji, R.F. Shen, et al. The key to $\mathrm{Mn}$ homeostasis in plants: regulation of $\mathrm{Mn}$ transporters. Trends Plant Sci. 22, 215-224 (2017)

17. S. Yang, K. Yi, M.M. Chang, et al. Sequestration of $\mathrm{Mn}$ into the cell wall contributes to Mn tolerance in sugarcane (Saccharum officinarum L.). Plant Soil, 436, 475-487 (2019) 